\title{
1. ZASTOSOWANIA TECHNOLOGII BLOCKCHAIN W FINANSACH
}

\author{
(iD) Hanna Kołodziejczyk \\ Uniwersytet Ekonomiczny w Poznaniu \\ hanna.kolodziejczyk@ue.poznan.pl \\ https://doi.org/10.18559/978-83-8211-083-8/1
}

\section{Applications of blockchain technology in finance}

\begin{abstract}
This chapter describes blockchain - an IT tool which has found an innovative use in finance, creating a new, fast-growing segment within FinTech. Blockchain, connected to the field of Distributed Ledger Technology, over the last few years has become a proposed solution for problems ranging from keeping financial records to designing new forms of money. The chapter establishes the foundations for further research by explaining what blockchain is and how it works, describing its characteristic features and weighing them against each other in a SWOT matrix. Following that, a number of proposed and already implemented applications of the technology are presented and discussed. This includes: cryptocurrencies, investment/security tokens and the process of tokenizing other types of real-world assets as well as digital repositories.
\end{abstract}

Keywords: blockchain; cryptocurrencies; bitcoin; SWOT.

\subsection{Wstęp}

Świat finansów zmienia się na naszych oczach za sprawą technologii blockchain. Ta wschodząca technologia ma duży potencjał, aby wstrząsnąć wieloma branżami - od rolnictwa po ubezpieczenia. Przypadki użycia są liczne i zróżnicowane: od programowalnych kryptowalut po zarządzanie aktami własności, śledzenie pochodzenia (provenance) aktywów i przeprowadzanie głosowań (Hileman i Rauchs, 2017). W ankiecie PwC w 2018 roku wśród 600 dyrektorów z 15 krajów 84\% stwierdziło, że ich organizacje są przynajmniej częściowo zaangażowane we wdrażanie technologi blockchain (PwC's global blockchain survey). W 2017 roku firma analityczna Gartner zaprognozowała globalną wartość dodaną innowacji technologicznych związanych z blockchain na 3,1 biliona dolarów w 2030 roku (Forecast, 2017). Można sobie wyobrazić, że do tego samego roku od $10 \%$ do $20 \%$ światowej infrastruktury gospodarczej będzie działać na systemach opartych na łańcuchu bloków (PwC's global blockchain survey). 
Sektor finansowy w dużym stopniu jest zależny od postępu technologicznego, szybko opierając dostarczane usługi na kolejnych innowacjach technologicznych, począwszy od telegrafu, przez internet, aż po uczenie maszynowe (Marchewka-Bartkowiak, 2019). Technologią, która najprawdopodobniej zmieni kolejną dekadę biznesu, nie są jednak sieci społecznościowe, duże zbiory danych, chmura, robotyka czy nawet sztuczna inteligencja. To blockchain, technologia kryjąca się między innymi za takimi cyfrowymi walutami jak bitcoin (Tapscott i Tapscott, 2016).

Celem tego rozdziału jest charakterystyka technologii blockchain. Przedstawiono w nim definicje, wskazano główne jej cechy oraz dokonano analizy strategicznej za pomocą metody SWOT. Następnie przedstawiono i scharakteryzowano możliwe finansowe zastosowania blockchaina, zwracając uwagę na dorobek literatury w tej dziedzinie. Rozdział kończy podsumowanie, w którym nakreślono dalsze perspektywy rozwoju technologii blockchain na świecie.

\subsection{Charakterystyka technologii blockchain}

Technologia blockchain nie jest sama w sobie innowacją z zakresu finansów. Stanowi ona narzędzie z zakresu IT, które zostało zastosowane jako fundament wielu innowacyjnych rozwiązań w dziedzinie finansów. Pierwszym praktycznym wdrożeniem tej technologii był bitcoin (Blockchain w Polsce). Przedstawione tu zostaną dwie definicje tego, czym jest blockchain: jedna techniczna i druga uwzględniająca jej pierwsze zastosowanie.

Blockchain to rozproszona, współdzielona i zaufana baza danych w formie łańcucha bloków zarządzana przez rozproszoną sieć równorzędnych uczestników (komputerów połączonych $\mathrm{w}$ ramach sieci $\mathrm{P} 2 \mathrm{P}$ - peer-to-peer), która zawiera historię wszystkich zweryfikowanych i zaakceptowanych zmian (transakcji). Protokołem blockchain określa się dodatkowo zbiór zasad tworzenia i weryfikacji transakcji, które odzwierciedlają zmiany oraz zasady osiągania konsensusu. Konsensus to automatyczny proces uzgadniania zgodności operacji w sieci blokchainowej (Blockchain w Polsce). Bardziej praktyczna definicja określa blockchain jako księgę rozrachunkową zawierającą listę transakcji (dokonywanych w danej kryptowalucie - o ile została ona przewidziana w danym blockchainie), a jednocześnie system transakcyjny (Piech, 2017).

Przełomowość rozwiązania zaproponowanego przez Satoshi' ego Nakamoto ${ }^{1}$ wynikała ze znalezienia rozwiązania zapewniającego niezaprzeczalność komunikacji

\footnotetext{
${ }^{1}$ Osoba Satoshi'ego Nakamoto owiana jest tajemnicą. W 2008 roku Nakamoto opublikował artykuł Bitcoin: A peer-to-peer electronic cash system, jednak jego prawdziwa tożsamość pozostaje nieznana.
} 
pomiędzy nieufającymi sobie podmiotami i jej zabezpieczenie przed fałszerstwem. Daje to podstawy do traktowania bazy jako zaufanej bez konieczności zaangażowania centralnej jednostki lub zaufanej strony trzeciej, a sama sieć może działać autonomicznie bez scentralizowanego nadzoru. Choć każdy uczestnik sieci ma wgląd do bazy danych (ma swoją kopię bazy i może inicjować i weryfikować zmiany), to nikt jej nie kontroluje, gdyż zmiany odbywają się poprzez konsensus wymuszony przez protokół.

Nazwa „blockchain” oznacza łańcuch bloków. Dane w bazie są zgrupowane w bloki, które są ze sobą powiązane w taki sposób, że każdy następny blok zawiera znacznik czasu, który określa, kiedy został stworzony, oraz odnośnik do poprzedniego bloku w formie hasha ${ }^{2}$ (pol. skrótu) jego zawartości. Każdy nowy blok jest dołączony na końcu łańcucha, powodując, że rozmiar blockchaina stale się powiększa ${ }^{3}$. Zmiana informacji zawartych w jednym z wcześniejszych bloków wymagałaby modyfikacji wszystkich następujących po nim bloków. Bloki mają określoną i ograniczoną wielkość, dlatego w przypadku zbyt dużej liczby transakcji oczekują one w kolejce na dodanie do kolejnego bloku ${ }^{4}$. Mimo wzrostu mocy sprzętu obliczeniowego szybkość tworzenia bloków w wielu publicznych blockchainach nie zwiększa się z biegiem czasu (co wynika z wbudowanego mechanizmu autoregulacji). Nowy blok blockchaina waluty bitcoin powstaje co ok. 10 minut, a waluty ether - co ok. 14 sekund (Cryptocurrency statistics, 2021).

Konsensus jest pojęciem bardzo ważnym w kontekście technologii blockchain. Definiuje on sposób, w który węzły w sieci (uczestnicy) podejmują decyzję o tym, czy konkretna transakcja może być zaakceptowana i dodana do bloku danych, co uczyniłoby ją niepodważalną̧. Istnieje wiele metod osiągania konsensusu, choć niektóre są stosowane powszechnie, a inne funkcjonują tylko na płaszczyźnie teoretycznej. Wybór metody ma konsekwencje dla bezpieczeństwa sieci oraz

${ }^{2}$ Hash jest to krótki ciąg znaków (zawsze stałej długości) przyporządkowany do pewnego dowolnie dużego zbioru danych za pomocą funkcji haszującej (funkcji skrótu). Jednym z zastosowań skrótu jest podpis elektroniczny.

${ }^{3}$ Rozmiar blockchaina Bitcoin przekracza 400 GB, a Ethereum sięga prawie 350 GB (Cryptocurrency statistics, 2021).

${ }^{4}$ Zazwyczaj kryterium dodania transakcji do blockchainu stanowi opłata transakcyjna zaoferowana przez wykonawcę transakcji, która stanowi wynagrodzenie dla uczestnika sieci angażującego moc obliczeniową do tworzenia nowego bloku.

${ }^{5} \mathrm{~W}$ rzeczywistości dodanie transakcji do nowo tworzonego bloku niekoniecznie czyni ją niepodważalną. W publicznej sieci Bitcoin uważa się, że dopiero uzyskanie sześciu potwierdzeń zapewnia prawdopodobieństwo bliskie pewności, że dana transakcja nie jest próbą podwójnego wydania środków. Liczba ta wynika z rozkładu prawdopodobieństwa dokonania skutecznego ataku przez osoby dysponujące $10 \%$ mocy obliczeniowej sieci. 
dla szybkości zatwierdzania nowych operacji ${ }^{6}$. Może ona stanowić przeszkodę w zwiększaniu skali działania sieci. Do najczęściej stosowanych sposobów osiągania konsensusu należą:

- proof of work (PoW),

- proof of stake (PoS),

- delegated proof of stake (DPoS),

- proof of authority (PoA).

Krótki opis niektórych sposobów osiągania konsensusu został zawarty w tabeli 1.1. Natomiast tabela 1.2 przedstawia ich porównanie pod kątem najważniejszych cech.

Tabela 1.1. Różne sposoby osiągania konsensusu w protokole blockchain

\begin{tabular}{|l|l|}
\hline \multicolumn{1}{|c|}{ Konsensus } & \multicolumn{1}{c|}{ Opis } \\
\hline Proof of work & $\begin{array}{l}\text { dowód wykonania pracy - wszystkie węzły mają możliwość zatwierdza- } \\
\text { nia nowego bloku, a prawdopodobieństwo dodania nowego bloku przez } \\
\text { węzeł rośnie wraz z zaangażowaniem większej mocy obliczeniowej (którą } \\
\text { wykorzystuje się do rozwiązania określonego problemu matematyczne- } \\
\text { go); przykład zastosowania: Bitcoin }\end{array}$ \\
\hline Proof of stake & $\begin{array}{l}\text { dowód stawki - im większą liczbę tokenów/jednostek waluty posiada } \\
\text { uczestnik sieci, tym większa szansa, że utworzy nowy blok; nagroda za } \\
\text { zatwierdzenie bloku jest rozdysponowywana zgodnie z liczbą posiada- } \\
\text { nych tokenów; przykład zastosowania: Ethereum zastępuje PoW przez } \\
\text { PoS w 2021 r. }\end{array}$ \\
\hline $\begin{array}{l}\text { Delegated proof of } \\
\text { stake }\end{array}$ & $\begin{array}{l}\text { delegowany dowód stawki - poprzez głosowanie posiadacze waluty wy- } \\
\text { bierają delegatów; tylko delegaci są uprawnieni do dodawania nowych } \\
\text { bloków; głosowanie odbywa się przy zatwierdzaniu każdego kolejnego } \\
\text { bloku; przykład zastosowania: BitShares }\end{array}$ \\
\hline $\begin{array}{l}\text { Provable data po- } \\
\text { ssession (PDP) }\end{array}$ & $\begin{array}{l}\text { użytkownik może wysłać dane na określony serwer i później sprawdzać, } \\
\text { czy nadal się tam znajdują }\end{array}$ \\
\hline $\begin{array}{l}\text { Proof of } \\
\text { retrievability }\end{array}$ & \begin{tabular}{l} 
rozwinięcie PDP; umożliwia również odzyskanie wysłanych danych \\
\hline Proof of storage
\end{tabular} \\
$\begin{array}{l}\text { użytkownik zleca innemu przechowywanie danych, a następnie wielokrot- } \\
\text { nie sprawdza, czy są one nadal przechowywane; stanowi uogólnienie PDP } \\
\text { i proof of retrievability }\end{array}$ \\
\hline Proof of space & użytkownik musi udowodnić, że poświęcił część swojej pamięci \\
\hline Proof of authority & $\begin{array}{l}\text { istnieją z góry wyznaczone węzły nadzorujące, które stale zajmują się } \\
\text { autoryzowaniem operacji }\end{array}$ \\
\hline
\end{tabular}

Źródło: opracowane na podstawie: (Piech, 2017, s. 22; Blockchain w Polsce, s. 19).

${ }^{6}$ Szybkość zatwierdzania bloków określa wydajność sieci. 
Tabela 1.2. Porównanie popularnych sposobów osiągania konsensusu

\begin{tabular}{|l|l|l|l|l|}
\hline Konsensus & \multicolumn{1}{|c|}{ Bezpieczeństwo } & \multicolumn{1}{|c|}{$\begin{array}{c}\text { Wydajność } \\
\text { i skalowalnośćc }\end{array}$} & \multicolumn{1}{|c|}{ Koszty } & Wykorzystanie \\
\hline PoW & $\begin{array}{l}\text { wysokie w przypad- } \\
\text { ku rozbudowanych } \\
\text { sieci }\end{array}$ & $\begin{array}{l}\text { niska wydajność } \\
\text { i bardzo ograniczona } \\
\text { skalowalność }\end{array}$ & $\begin{array}{l}\text { bardzo wysokie } \\
\text { (głównie z powodu } \\
\text { kosztów energii } \\
\text { elektrycznej) }\end{array}$ & $\begin{array}{l}\text { sieci publiczne, } \\
\text { wykorzystujące } \\
\text { kryptowaluty }\end{array}$ \\
\hline PoS & $\begin{array}{l}\text { niższe niż PoW, } \\
\text { zależne od dywer- } \\
\text { syfikacji tokenów } \\
\text { (rośnie wraz z dużą } \\
\text { dywersyfikacją) }\end{array}$ & $\begin{array}{l}\text { wyższa niż w przy- } \\
\text { padku PoW, jednak } \\
\text { ograniczona od } \\
\text { pewnego momentu } \\
\text { rozwoju }\end{array}$ & niższe niż w PoW & $\begin{array}{l}\text { sieci publiczne } \\
\text { lub hybrydowe }\end{array}$ \\
\hline DPoS & $\begin{array}{l}\text { wyższe niż w przy- } \\
\text { padku PoS }\end{array}$ & $\begin{array}{l}\text { wyższa niż w przy- } \\
\text { padku PoW, jednak } \\
\text { ograniczona od } \\
\text { pewnego momentu } \\
\text { rozwoju }\end{array}$ & niższe niż w PoW & $\begin{array}{l}\text { sieci publiczne } \\
\text { lub hybrydowe }\end{array}$ \\
\hline PoA & $\begin{array}{l}\text { zależne od liczby } \\
\text { jednostek nadzoru- } \\
\text { jących sieć (rośnie } \\
\text { wraz z liczbą tych } \\
\text { jednostek) }\end{array}$ & $\begin{array}{l}\text { bardzo wysoka } \\
\text { wydajność i skalo- } \\
\text { walność zależna od } \\
\text { nakładów na sprzęt }\end{array}$ & $\begin{array}{l}\text { niższe niż w PoW, } \\
\text { zależne od liczby } \\
\text { jednostek nadzoru- } \\
\text { jących sieć }\end{array}$ & sieci prywatne \\
\hline
\end{tabular}

Źródło: (Blockchain w Polsce, s. 19).

Należy wspomnieć przede wszystkim o pewnych konsekwencjach wywołanych upowszechnieniem stosowania technologii blockchain. PoW, stosowany w sieci Bitcoin, przyczynił się do powstania nowego przemysłu produkującego sprzęt przeznaczony do autoryzowania transakcji w tej sieci oraz do wzrostu cen kart graficznych, które okazały się możliwe do wykorzystania w procesie „kopania” kryptowalut. Proces wydobywania bitcoinów powoduje bardzo duże zużycie energii elektrycznej (co wiąże się z dużymi kosztami) na skalę światową̧. Inne sposoby osiągania konsensusu również wywołują nieoczekiwane wahania rynkowe, co można prześledzić na przykładzie kryptowaluty chia, która w maju 2021 roku

${ }^{7}$ Kopanie (mining) lub wydobywanie to słowa używane do określenia procesu tworzenia nowej jednostki waluty bitcoin (lub innych kryptowalut). Zajmują się tym uczestnicy sieci, tzw. górnicy.

${ }^{8}$ Zużywanie energii elektrycznej do kopania bitcoinów rodzi kontrowersje natury etycznej (alokacja ograniczonych zasobów prądu do wykonania zadań o niekoniecznie wysokim priorytecie społecznym) i ekologicznej (w krajach, w których wydobywana jest znaczna część bitcoinów, na przykład w Chinach, prąd pochodzi zazwyczaj ze źródeł nieodnawialnych). W maju 2021 roku głos w tej dyskusji zajął Elon Musk, a jego tweet przyczynił się, zdaniem inwestorów, do dużego spadku ceny bitcoina (Otani, 2021). 
została obwiniona o wzrost cen i spadek podaży pewnego typu dysków SSD9 . $\mathrm{Z}$ drugiej strony wiele instytucji wskazuje na pozytywny wpływ walut cyfrowych na gospodarkę (Marszałek, 2019).

Bitcoin stanowi przykład blockchaina publicznego, jednak nie wszystkie blockchainy funkcjonują w sieci publicznej. Istnieją trzy zasadnicze rodzaje sieci blockchainowych: publiczne, prywatne i hybrydowe (Blockchain w Polsce). Różnice pomiędzy nimi mają charakter fundamentalny, odróżnienie ich ma kluczowe znaczenie dla zrozumienia, że nie każde rozwiązanie oparte na technologii blockchain charakteryzuje się tymi samymi cechami co Bitcoin. Do sieci publicznej może się podłączyć każdy, a sama sieć funkcjonuje w zdecentralizowany, autonomiczny sposób. Węzły sieci są równorzędne, zatem nie ma jednostki odpowiedzialnej za nadzór. Sieć prywatna jest najczęściej tworzona na potrzeby zamkniętej organizacji lub ich grupy. Dostęp do niej mają tylko jednostki wewnątrz organizacji, a zasady funkcjonowania są kształtowane przez jednostkę nadzorującą. Sieć hybrydowa stanowi połączenie obu typów. Często jest to sieć prywatna wykorzystująca infrastrukturę sieci publicznej. Innym kryterium podziału sieci blockchainowych są sieci permissionless (bez zezwolenia) oraz permissioned (z zezwoleniem) (Blockchain w Polsce). Macierz możliwości uzyskanych z połączenia obu opisanych kryteriów ilustruje tabela 1.3. W przypadku użytkowników biznesowych najczęściej wybierana jest sieć prywatna z zezwoleniem (Deloitte, 2020).

Tabela 1.3. Macierz możliwych rozwiązań budowy sieci blockchain

\begin{tabular}{|c|c|c|}
\hline Typ sieci & $\begin{array}{l}\text { Permissionless } \\
\text { (bez zezwolenia) }\end{array}$ & $\begin{array}{c}\text { Permissioned } \\
\text { (z zezwoleniem) }\end{array}$ \\
\hline Publiczna & $\begin{array}{l}\text { operacje dostępne dla wszyst- } \\
\text { kich: dostęp, odczyt, zapis } \\
\text { i zatwierdzanie } \\
\text { wysoki poziom anonimowo- } \\
\text { ści i bezpieczeństwa; niska } \\
\text { skalowalność }\end{array}$ & $\begin{array}{l}\text { operacje dostępne dla wszystkich: dostęp i odczyt } \\
\text { operacje dostępne tylko dla uprawnionych użyt- } \\
\text { kowników: zapis i zatwierdzanie } \\
\text { średnia skalowalność }\end{array}$ \\
\hline Prywatna & $\begin{array}{l}\text { rozwiązanie nie jest stosowane } \\
\text { w praktyce }\end{array}$ & $\begin{array}{l}\text { operacje dostępne tylko dla uprawnionych użyt- } \\
\text { kowników: dostęp i odczyt } \\
\text { zapis i zatwierdzanie dostępne tylko dla operatora } \\
\text { sieci/jednostki nadzorującej } \\
\text { wysoka skalowalność }\end{array}$ \\
\hline
\end{tabular}

Źródło: (Deloitte, 2020, s. 4).

${ }^{9}$ Kryptowaluta chia stosuje proof of spacetime jako metodę osiągania konsensusu, która, choć nie wymaga dużych ilości energii elektrycznej, wymaga przechowywania danych na dysku z sekwencją sprawdzeń rozłożoną w czasie. W tym celu najlepiej sprawdzają się dyski NVMe, na które popyt nagle wyraźnie wzrósł (Hern, 2021). 


\subsection{Analiza SWOT stosowania technologii blockchain}

Wybuchowy wzrost zainteresowania technologią blockchain i jej różnorodnymi zastosowaniami prowadzi czasem do bezkrytycznego zachwytu i przekonania, że blockchain jest najlepszą architekturą dla wszelkich projektów biznesowych. Tak jak w odniesieniu do innych nowych rozwiązań technologicznych konieczna jest jednak krytyczna refleksja nad mocnymi i słabymi stronami tej technologii oraz szansami i zagrożeniami stojącymi przed jej rozwojem.

\section{Mocne strony}

Za zaletę technologii należy uznać możliwość tworzenia niezaprzeczalnych, zaufanych rejestrów. Dane zapisywane w bloku są niezmienne i nieodwracalne, a rejestru nie można sfałszować. Rozwiązania oparte na blockchainie pozwalają na automatyczne działanie, bez konieczności angażowania pośredników lub podmiotów służących jako zaufana strona trzecia. Prowadzi to do spadku kosztów. Prawdopodobnie najważniejszą zaletą technologii jest jej elastyczność. Pozwala ona na przygotowanie rozwiązań dostosowanych do indywidulanych potrzeb, głównie dzięki możliwości wyboru między siecią publiczną i prywatną. Blockchain oferuje decentralizację, skalowalność ${ }^{10} \mathrm{i}$ bezpieczeństwo sieci, choć należy mieć na uwadze, że cechy te występują z różnym nasileniem. Blockchain stanowi platformę umożliwiającą cyfrową reprezentację dóbr fizycznych (tokenizacja) czy też zapis reguł biznesowych pod postacią kodu (inteligentne kontrakty).

\section{Słabe strony}

Z drugiej strony blockchain jest nadal młodą, niedojrzałą i niewystarczająco przetestowaną technologią. Jedną z jej istotnych wad jest to, że w praktyce niemożliwe jest jednoczesne zapewnienie decentralizacji, skalowalności i bezpieczeństwa. Rozwiązania oferujące dwie spośród tych trzech cech nie będą w stanie zapewnić trzeciej (Deloitte, 2020). Każde zwiększenie bezpieczeństwa lub wydajności będzie się odbywało koszem drugiego parametru. Choć publiczny blockchain zapewnia wysoki poziom anonimowości, nie jest to jednak anonimowość doskonała. Informacje o wszystkich transakcjach w sieci w zestawieniu z dodatkowymi informacjami zewnętrznymi oraz przy zastosowaniu zaawansowanych technik analitycznych częściowo umożliwiają identyfikację osób (Piech, 2017). W badaniu PwC za jedne z największych barier we wdrożeniu technologii w danej

${ }^{10}$ Skalowalność (scalability) to możliwość zwiększenia skali działania systemu, czyli jego zdolność do sprawnego działania w warunkach rosnącej liczby użytkowników i zwiększającego się zakresu przetwarzanych danych (por. Stownik języka polskiego, www.sjp.pl). 
branży uznano brak interoperacyjności między osobnymi sieciami blockchain oraz (wspomnianą wcześniej) niedostateczną skalowalność ( $P w C$ 's global blockchain survey). Blockchain jest podatny na tzw. atak $51 \%$, czyli atak na sieć polegający na przejęciu przez atakującego kontroli nad ustalaniem konsensusu (na przykład poprzez przejęcie ponad połowy całkowitej mocy obliczeniowej komputerów podłączonych do danej sieci). Prawdopodobieństwo takiego zdarzenia zależy między innymi od tego, jak dobrze zdecentralizowana jest sieć.

\section{Szanse}

Należy się przyjrzeć globalnym trendom, które blockchain mógłby wykorzystać na swoją korzyść, czyli szansom rozwoju. Rośnie popularność blockchaina jako rozwiązania technologicznego. Technologia znajduje zastosowania w kolejnych branżach. Choć pierwotnie na pozycji lidera we wdrażaniu technologii uplasował się sektor finansowy, najnowsze trendy pokazują, że zainteresowanie blokchainem wzrasta w innych gałęziach gospodarki, na przykład w produkcji przemysłowej, sektorze energii, usługach użyteczności publicznej i opiece zdrowotnej. Dodatkowo przed blockchainem otwiera się również nowy rynek w ujęciu geograficznym, gdyż przewidywania ekspertów wskazują, że wkrótce liderem we wdrażaniu technologii mogą stać się Chiny, zastępując USA ( $P w C$ s' global blockchian survey). Szersze zainteresowanie blockchainem w biznesie oznacza, że popularyzują się rozwiązania typu blockchain-as-a-service (czyli platformy oferowane w ,chmurze”) oferowane zarówno przez wielkie firmy (Microsoft, Amazon, Oracle), jak i mniejsze (Chain) (Blockchain w Polsce). Globalne trendy, które mogą stanowić szansę rozwoju dla blochchaina, to na przykład wysoki koszt scentralizowanych rozwiązań technologicznych, wysoki koszt i powolność transferu aktywów przy wykorzystaniu tradycyjnych metod i technologii, generowanie przez przedsiębiorstwa dużych ilości informacji (big data), które muszą być przechowywane i analizowane. Eksperci oceniają, że w najbliższym czasie zaangażowanie rządów państw w rozwiązania oparte na tej technologii ${ }^{11}$ będzie rosnąć (The blockchain report, 2020), co daje nadzieję na prawne uregulowanie rozwiązań opierających się na blockchainie.

\section{Zagrożenia}

Aby móc się rozwijać bez przeszkód, blochchain musi się jednak zmierzyć z zagrożeniami na przykład ze strony otoczenia prawnego i czynników społecznych. Odpowiedzi uzyskane w cytowanym już badaniu PwC pokazały, że największymi barierami w stosowaniu tej technologii są zmieniające się regulacje prawne oraz brak zaufania do blockchaina wśród jego użytkowników. Na dalszych miejscach

${ }^{11}$ Przykładem zaangażowania w rozwiązania blockchainu na szczeblu państwowym są inicjatywy CBDC (central bank digital currency). 
wskazywano obawy w zakresie własności intelektualnej oraz zgodności z innymi regułami. Na przykład przechowywanie danych osobowych na blockchainie może stać w sprzeczności z zasadą prawa do bycia zapomnianym, bowiem zapisów na blockchainie nie można usunąć. Wydaje się więc, że przepisy prawa, o ile nie zostaną zmienione, wyznaczają granicę w rozwoju blockchaina. Społeczne nastawienie wobec tej technologii nadal oscyluje między ostrożnością i wątpliwościami a ,hurraoptymizmem” prowadzącym do nadużywania technologii w sytuacjach, w których nie jest konieczna, co w przyszłości może grozić rozczarowaniem i przedwczesnym wycofaniem się ze ścieżki rozwoju.

Czynnikiem ryzyka dla powodzenia projektów blockchainowych jest ponadto jakość danych oraz czynnik ludzki odpowiedzialny za wdrożenie konkretnych rozwiązań. To, że dane na blockchainie nie mogą być zmienione, nie oznacza, że są one poprawne, a dowolny kod pisany przez programistę może zawierać błędy. By uniknąć ryzyka przy wdrażaniu rozwiązania biznesowego, konieczne są wyczerpujące testy, które zwiększą jego koszty.

Jako podsumowanie powyższych rozważań w tabeli 1.4 syntetycznie zaprezentowano najważniejsze mocne i słabe strony oraz szanse i zagrożenia technologii blockchain.

Tabela 1.4. Analiza SWOT technologii blockchain

\begin{tabular}{|c|c|}
\hline Mocne strony & Slabe strony \\
\hline $\begin{array}{l}\text { - niezaprzeczalny, zaufany rejestr } \\
\text { - brak potrzeby angażowania pośrednika } \\
\text { lub zaufanej strony trzeciej } \\
\text { - możliwość obniżenia kosztów } \\
\text { - elastyczność } \\
\text { - rozwiązania szyte na miarę }\end{array}$ & $\begin{array}{l}\text { - niedojrzała i niewystarczająco przetestowa- } \\
\text { na technologia } \\
\text { - konieczność rezygnacji z jednej spośród } \\
\text { trzech cech: decentralizacji, skalowalności } \\
\text { lub bezpieczeństwa } \\
\text { - zapewniona przez sieć anonimowość nie jest } \\
\text { doskonała } \\
\text { - brak interoperacyjności między sieciami } \\
\text { - technologia podatna na tzw. atak } 51 \%\end{array}$ \\
\hline Sza & Za \\
\hline $\begin{array}{l}\text { - duża popularność technologii } \\
\text { - tworzenie się nowych zastosowań w kolej- } \\
\text { nych branżach gospodarki } \\
\text { - otwieranie się nowych rynków } \\
\text { geograficznych } \\
\text { - oferowanie blockchaina jako usługi } \\
\text { w chmurze } \\
\text { - wysokie koszty alternatywnych rozwiązań } \\
\text { - trend dig data generujący duże ilości danych } \\
\text { - wprowadzenie prawnych regulacji } \\
\text { technologii }\end{array}$ & $\begin{array}{l}\text { - zbyt często zmieniające się otoczenie } \\
\text { prawne } \\
\text { - brak zaufania do technologii ze strony jej } \\
\text { użytkowników } \\
\text { - obawy w zakresie własności intelektual- } \\
\text { nej i zgodności z przepisami nt. danych } \\
\text { osobowych } \\
\text { - nadużywanie technologii w sytuacjach, gdy } \\
\text { nie jest to uzasadnione, grozi rozczarowa- } \\
\text { niem społecznym } \\
\text { - błędy ze strony czynnika ludzkiego }\end{array}$ \\
\hline
\end{tabular}

Źródło: opracowanie własne. 


\subsection{Finansowe zastosowania technologii blockchain}

Dane zapisywane w rozproszonej bazie danych, którą jest blockchain, można wykorzystać do unikalnego zidentyfikowania pewnych aktywów. Stąd też blockchain wykorzystuje się do przeprowadzenia tzw. tokenizacji - rejestracji rzeczywistych aktywów w łańcuchu bloków. Cyfrowe reprezentacje istniejących zasobów są nazywane tokenami ${ }^{12}$. OECD stwierdza, że token cyfrowy odzwierciedla przeniesienie praw do zasobu świata rzeczywistego na jego cyfrową reprezentację i stwarza też możliwość handlu nim i śledzenia go w świecie wirtualnym (Marchewka-Bartkowiak, 2019).

Klasyfikacja tokenów nie jest zagadnieniem trywialnym, stanowi szczególne wyzwanie dla instytucji odpowiedzialnych za regulowanie rynku finansowego, które często podkreślają, że dokładna ocena indywidualnych realiów ekonomicznych leżących u podstaw transakcji jest ważniejsza niż określenie przypisane danemu tokenowi (OECD, 2019, s. 47). W zależności od kontekstu tokeny mogą się zachowywać w sposób zbliżony do waluty (tokeny płatnicze - payment/exchange tokens), papieru wartościowego (tokeny inwestycyjne lub udziałowe - security tokens) lub bonu uprawniającego do wymiany na określone dobra lub usługi oferowane przez emitenta tokenu (tokeny użytkowe - utility tokens) (Deloitte, 2019; Marchewka-Bartkowiak, 2019). Mogą być one emitowane przez prywatne instytucje (tokeny instytucjonalne) lub przez indywidulane osoby (tokeny personalne) (Marchewka-Bartkowiak, 2019).

Przykładem tokena płatniczego jest bitcoin, który jest ponadto określany mianem kryptowaluty. Kryptowaluty można uznać za pewien szczególny podtyp walut wirtualnych, które operują na zasadzie zdecentralizowanej (peer-to-peer), a nie są emitowane przez bank centralny (Bech i Garratt, 2017), przy czym przez waluty wirtualne należy rozumieć pieniądz elektroniczny emitowany i zazwyczaj kontrolowany przez jego twórców oraz używany i akceptowany przez członków określonej wirtualnej społeczności (Europejski Bank Centralny [EBC], 2012).

Bitcoin bardzo dobrze wpisał się w trendy nowej gospodarki oraz zdecentralizowanych finansów (DeFi). Jest oparty na technologii blockchain, zapewnia swoim użytkownikom niemal doskonałą anonimowość ${ }^{13}$, a zarazem jest przejrzysty (rejestr transakcji jest publiczny, a kod ma charakter open source). Jego

${ }^{12}$ Tak zdefiniował tokeny Europejski Bank Centralny - tokenizację traktuje jako reprezentację istniejącego zasobu za pomocą innych środków lub w innych formach niż oryginalna (EBC, 2019).

${ }^{13}$ Jak zaznaczono już wcześniej, należałoby użyć raczej sformułowania pseudonimowość. Oczywiście wywołuje to kontrowersje dotyczące wykorzystania kryptowalut w handlu nielegalnymi dobrami i usługami. Analizy sugerują jednak, że dla przestępców wykorzystanie kryptowalut jest na ogół zbyt trudne lub zbyt mało anonimowe (Wikarczyk, 2019). 
bezpieczeństwo (wynikające z użycia kryptografii asymetrycznej) i decentralizacja (rezygnacja z emisji związanej z bankiem centralnym na rzecz zdecentralizowanej sieci peer-to-peer) to tylko niektóre z cech, które są uznawane za jego zalety. Bitcoin zapoczątkował trend kreacji nowych kryptowalut, których liczba, jakkolwiek niemożliwa do dokładnego oszacowania ${ }^{14}$, przekracza 10 tysięcy $^{15}$.

Mimo dużej popularności bitcoin i inne kryptowaluty wywołują wiele kontrowersji dotyczących między innymi ich statusu prawnego ${ }^{16}$ oraz roli jako pienią$\mathrm{dza}^{17}$. Funkcje pieniądza (środka płatniczego, środka tezauryzacji oraz miernika wartości) nie są przez bitcoin spełniane całkowicie, a jedynie w pewnym ograniczonym stopniu (Marszałek, 2019). Na przeszkodzie dużo szerszego upowszechnienia bitcoina jako środka płatniczego stoi w dużej mierze bardzo wysoka zmienność jego kursu ${ }^{18}$, co wpisuje się w reputację kryptowalut jako aktywów spekulacyjnych.

Istnieją dwa sposoby pozyskiwania kryptowaluty: wydobycie i zakup na rynku wtórnym. W przypadku wydobywania kryptowalut uzyskuje się je w zamian za zaangażowanie mocy obliczeniowej (jeśli obowiązującą metodą konsensusu jest PoW, w przeciwnym wypadku jest to na przykład udostępnienie przestrzeni dyskowej), która jest potrzebna do weryfikacji dokonywanych w danej kryptowalucie transakcji ${ }^{19}$. Niektórych kryptowalut nie można wydobyć, można je jedynie nabyć od podmiotu odpowiedzialnego za ich emisję. Nabycie kryptowalut odbywa się z kolei na jeden z czterech sposobów (Wikarczyk, 2019):

- bezpośrednio od innego użytkownika,

- w kantorach kryptowalutowych,

- w bankomatach bitcoinowych,

- na giełdzie kryptowalut.

Kryptowaluty przechowuje się w portfelu (wallet) lub sejfie (vault) - w formie cyfrowej. Portfelem jest oprogramowanie (aplikacja) lub urządzenie, które przechowuje prywatne i publiczne klucze ${ }^{20}$ oraz wchodzi w interakcje, umożliwiając

${ }^{14}$ Stworzenie nowej kryptowaluty jest relatywnie proste. Wiele kryptowalut ma jednak charakter zamknięty i prywatny, co uniemożliwia ich policzenie.

${ }^{15}$ Powszechnie stosowane źródło informacji o rynku kryptowalut, internetowy portal coinmarketcap.com, szacuje liczbę kryptowalut na 10192 (Coinmarketcap, 2021).

${ }^{16}$ Obrót kryptowalutami, w zależności od kraju, bywa legalny, ograniczony lub nielegalny (Marszałek, 2019).

${ }^{17}$ Szerzej na ten temat można przeczytać w artykułach: (Glaser, Zimmermann, Haferkorn, Weber i Siering, 2014; Baur, Hong i Lee, 2017).

${ }^{18}$ Średnia miesięczna zmienność kursu bitcoina jest wyższa niż zmienność cen złota lub grupy walut obcych (Dwyer, 2015).

${ }^{19}$ Górnicy otrzymują również bitcoiny z opłat za transakcje, które weszły do bloku.

${ }^{20}$ Przy zastosowaniu metod kryptografii asymetrycznej generowane są dwa typy kluczy: publiczny (jawny) i prywatny (tajny). 
przesyłanie i otrzymywanie kryptowalut. Portfele nie przechowują środków (jednostek waluty), lecz klucz prywatny dający do nich dostęp. Środki są przypisane do klucza w blockchainie (Piech, 2017). Trzymanie środków na giełdach kryptowalutowych jest ryzykowne. W przeszłości zdarzały się sytuacje, gdy giełdy bez ostrzeżenia zawieszały swoją działalność ${ }^{21}$. Przyczyn utraty środków może być wiele: atak hakerski na giełdę, celowa defraudacja, zajęcie sprzętu przez organy ścigana, losowe zdarzenia (awaria serwera lub nagła śmierć jedynej osoby posiadającej hasła dostępu do systemów giełdy ${ }^{22}$ ).

Powstało wiele projektów i firm, które zapewniają produkty i usługi ułatwiające korzystanie z kryptowalut przez ich użytkowników i budują infrastrukturę dla aplikacji działających na publicznych łańcuchach bloków - ekosystem kryptowalut. W skład tego ekosystemu wschodzą podmioty zaangażowane w następujące usługi: giełdy, portfele, płatności i wydobywanie (Hileman i Rauchs, 2017).

Na liście pięciu kryptowalut notujących największe dzienne obroty ${ }^{23}$ znajdują się: tether, bitcoin, ether, binance USD i XRP. Ether jest natywną kryptowaluta platformy Ethereum. Jest to obecnie najpopularniejsza zdecentralizowana platforma zbudowana na technologii blockchain obsługująca inteligentne kontrakty (smart contracts) oraz zdecentralizowane aplikacje dApps. Wiele innych kryptowalut funkcjonuje jako wymienialne tokeny w standardzie ERC-20 na blockchainie Ethereum, którą wykorzystały do przeprowadzenia ICO (initial coin offering). Ethereum umożliwia również kreację i wymianę tokenów niewymienialnych (non-fungible tokens, NFT) ${ }^{24}$, służących do reprezentacji przedmiotów materialnych i niematerialnych o unikalnych cechach (Marchewka-Bartkowiak, 2019).

Tether i binance USD stanowią przykłady stablecoinów. Na tle innych kryptowalut stablecoiny wyróżnia obietnica dużo niższych wahań kursowych. Stablecoiny to cyfrowe jednostki wartości, które nie stanowią formy jakiejkolwiek waluty (lub ich koszyka), a raczej posługując się zestawem narzędzi stabilizujących, można minimalizować fluktuacje ich ceny w tych walutach (Bullmann, Klemm i Pinna, 2019). Stablecoiny są wykorzystywane na rynku z trzech głównych powodów (Calle i Zalles, 2019):

- aby wyprowadzić zyski z inwestycji, czyli są tymczasowym instrumentem przechowywania wartości bez konieczności opuszczania rynku kryptowalut;

- odgrywają rolę „raju podatkowego”, czyli narzędzia do unikania opodatkowania;

- umożliwjają uzyskanie dostępu do waluty referencyjnej (na przykład USD) poza jej systemem bankowym.

${ }^{21}$ Za przykład może służyć polska giełda Bitcurex (Wikarczyk, 2019).

${ }^{22}$ Dotknęło to kanadyjską giełdę Quadriga (Shane, 2019).

${ }^{23}$ Obroty na dzień 1.06 .2021 roku zgodnie $\mathrm{z}$ danymi portalu coinmarketcap.com.

${ }^{24} \mathrm{Za}$ przykład niewymienialnego tokenu na blockchainie Ethereum mogą służyć CryptoKitties. 
Często wykorzystywanym w konstrukcji stablecoinów mechanizmem stabilizującym jest utrzymywanie zabezpieczenia ${ }^{25}$ wartości wyemitowanych stablecoinów przez powiernika połączone z gotowością podmiotu zarządzającego do odkupu wyemitowanych jednostek i zwrotu zabezpieczenia na żądanie ich posiadacza. Dla większości stablecoinów USD stanowi walutę odniesienia, tzn. że utrzymują one stabilny kurs wobec USD. Pozycja tethera wśród stablecoinów jest silna mimo kontrowersji, które wzbudza ${ }^{26}$ (Kołodziejczyk i Jarno, 2020).

XRP stanowi natywną walutę systemu Ripple. Protokół Ripple pozwala na zabezpieczone kryptograficznie transfery wartości w sieci peer-to-peer (rozproszony rejestr danych). Przewagą sieci Ripple nad tradycyjnym systemem płatności i rozliczeń międzybankowych jest jej szybkość (realizacja w kilka sekund) i niskie koszty (opłaty transakcyjne dużo niższe niż przy użyciu tradycyjnych pośredników) (Blockchain w Polsce). Transakcje mają charakter nieodwracalny, co w zależności od kontekstu może stanowić zaletę lub wadę. Choć system Ripple stanowi interesującą alternatywę dla systemu płatności, wyzwaniem dla jego rozwoju jest skalowalność (Blockchain w Polsce) ${ }^{27}$. W grudniu 2020 roku U.S. Securities and Exchange Commission (SEC) wszczęła postępowanie przeciw firmie Ripple Labs za sprzedaż tokenów XRP, które SEC zaklasyfikowała jako niezarejestrowane papiery wartościowe (Popper, 2020).

Działalność projektów opartych na technologii blockchain często odbywa się za pośrednictwem ICO - initial coin offering. ICO jest metodą pozyskiwania kapitału poprzez sprzedaż tokenów dających ich posiadaczom prawa majątkowe (security tokens) lub dostęp do usług oferowanych przez daną platformę (tokeny użytkowe) (Blockchain w Polsce). Ponieważ charakter tej zbiórki jest zazwyczaj publiczny, ICO można uznać za jedną z form crowdfundingu. Nazwa ICO nie przez przypadek nawiązuje do pierwszej oferty publicznej papierów wartościowych IPO (initial public offering) ${ }^{28}$. Większość ICO odbywa się na platformie Ethereum, a tokeny są sprzedawane w zamian za pieniądze lub kryptowaluty (na przykład bitcoin lub ether) z wykorzystaniem funkcjonalności inteligentnych kontraktów (Piech, 2017). Pierwsze ICO odbyło się w 2013 roku, a wartość pieniędzy zainwestowana w ICO wciąż rośnie. Więcej szczegółów na ten temat przedstawiono w rozdziale czwartym.

${ }^{25}$ Zabezpieczenie mogą stanowić: jednostki waluty referencyjnej, jednostki kryptoaktywów, na przykład jednostki innej kryptowaluty, inne aktywa, w tym niefinansowe, na przykład złoto.

${ }^{26}$ Do największych kontrowersji należą wątpliwości, czy emisja tetherów rzeczywiście jest w 100\% zabezpieczona rezerwami USD, oraz oskarżenia, które sugerują, że tether był wykorzystywany do manipulowania kursem bitcoina (Kołodziejczyk i Jarno, 2020).

${ }^{27}$ Zastrzeżenia ze strony banków zostały podsumowane stwierdzeniem „nie da się umieścić całego świata na blockchainie"(Irrera, 2018).

${ }^{28}$ Porównanie tradycyjnych form finansowania dla sektora MŚP (IPO, crowdfunding i venture capital) z ICO można znaleźć w raporcie OECD (OECD, 2019). 
Podobieństwa między ICO i IPO (które są uregulowane prawnie i stawiają warunki emitentom) powodują, że niektóre instytucje nadzorujące rynki finansowe zdecydowały się traktować (analizując każdy przypadek osobno) część tokenów jako papiery wartościowe na podstawie istniejących przepisów ${ }^{29}$, podczas gdy inne zadecydowały o zakazie przeprowadzania $\mathrm{ICO}^{30}$. Część państw już przygotowała ustawodawstwo odnoszące się bezpośrednio do kwestii emisji papierów wartościowych z użyciem blockchaina (Deloitte, 2019). W 2017 roku ESMA zidentyfikowała następujące rodzaje ryzyka wiążące się z inwestycją w ICO (ESMA, 2017):

- przestrzeń nieuregulowana, podatna na próby oszustwa lub nielegalne działania ${ }^{31}$;

- wysokie ryzyko utraty całego zainwestowanego kapitału;

- brak strategii wyjścia i ekstremalna zmienność cen;

- niewystarczające informacje;

- wady technologii ${ }^{32}$.

Działania zmierzające do objęcia przepisami prawa zjawiska emisji tokenów o cechach papierów wartościowych $\mathrm{w}$ ramach uregulowanej prawnie procedury STO (security token offering) są podejmowane na szczeblu zarówno krajowym, jak i międzynarodowym. Następstwem zakwalifikowania security tokens jako instrumentów finansowych w zgodzie z dyrektywą MiFID byłoby objęcie ich wymogami obowiązującymi we wszystkich istniejących przepisach UE dotyczących papierów wartościowych ${ }^{33}$. Osobną, lecz powiązaną kwestię stanowi regulacja procesu tokenizacji istniejących aktywów (w tym papierów wartościowych) w ramach technologii blockchain ${ }^{34}$. Z regulacyjnego punktu widzenia proces tokenizacji nie powinien mieć wpływu na status aktywów, pod warunkiem że nie nastąpią żadne zmiany w statusie prawnym aktywów bazowych. Jednak środowisko technologii rozproszonego rejestru, w którym znajduje się token, może zmienić granice, w których przepisy mają zastosowanie (Deloitte, 2019).

${ }^{29}$ Wspomniany powyżej przypadek decyzji SEC wobec Ripple Labs.

${ }^{30} \mathrm{~W}$ Chinach od 2017 roku obowiązuje zakaz przeprowadzania ICO (Acheson, 2017).

${ }^{31}$ Niektóre portale i media społecznościowe wprowadziły w 2018 roku zakazy lub ograniczenia reklam powiązanych z ICO.

${ }^{32} \mathrm{~W} 2017$ roku celem ataków hakerskich były ICO przeprowadzone przez CoinDash i Enigma (Memoria, 2017).

${ }^{33}$ Do tokenów zastosowanie mogłyby mieć między innymi MiFID II/MiFIR, Central Securities Depositories Regulation (CSDR) i Settlement Finality Directive (SFD), regulacje dotyczące krótkiej sprzedaży (Short Selling Regulation), dyrektywa AIFM, regulacje EMIR, dyrektywa AMLD i procedury KYC (Deloitte, 2019).

${ }^{34}$ Tokenizacja może się przyczynić do usprawnienia procesu emisji (STO), obrotu (rynek wtórny), rozliczania i rozrachunku papierów wartościowych. 
Technologia blockchain może być wykorzystywana na wszystkich obszarach związanych z obecnością papierów wartościowych na rynku finansowym (Deloitte, 2019):

- na rynku pierwotnym rozwiązania blockchainowe mogą ułatwić proces emisji i dopuszczenia papierów wartościowych na rynek oraz rejestracji w centralnym depozycie papierów wartościowych;

- w obszarze rynku wtórnego tokeny mogą być notowane na rynku regulowanym, wielostronnej platformie obrotu (MTF) lub zorganizowanej platformie obrotu (OTF);

- w infrastrukturze posttransakcyjnej usługi oparte na blockchainie mogą znaleźć zastosowanie w rozliczeniach, rozrachunku i usługach CCP (central counterparty);

- w ramach innych usług związanych z obsługą papierów wartościowych, na przykład usług powierniczych oraz usług pożyczania papierów wartościowych i zarządzania zabezpieczeniem.

Przykładem przedsiębiorstwa, które podjęło się oferowania usług opartych na blockchainie w ramach istniejącego prawa regulującego funkcjonowanie rynku finansowego, jest ID2S. W 2018 roku ID2S otrzymało licencję francuskiego nadzorcy nad rynkiem finansowym AMF na prowadzenie centralnego depozytu papierów wartościowych (krótkoterminowych papierów dłużnych przedsiębiorstw), wykorzystując technologię blockchain dostarczaną przez SETL (ID2S, 2021). Prace nad rozwiązaniami unowocześniającymi istniejący model emisji, obrotu i zarządzania papierami wartościowymi prowadzą również Malta Stock Exchange, SIX Swiss Exchange oraz Clearstream (Deloitte, 2019).

Istnieje także wiele polskich inicjatyw opartych na blockchainie, rozwijanych zarówno przez duże instytucje rynku finansowego, jak i start-upy. Platforma Blockchain dla Rynku Kapitałowego jest oferowana uczestnikom rynku kapitałowego przez Krajowy Depozyt Papierów Wartościowych. Aplikacja eVoting jest pierwszą z usług, jaką KDPW udostępnił w ramach platformy. Jej zadaniem jest obsługa walnych zgromadzeń spółek publicznych (KDPW, 2021). Giełda Papierów Wartościowych w Warszawie pracuje nad rozwojem nowego rynku pod nazwą GPW Private Market. Ma on stanowić miejsce obrotu stokenizowanymi aktywami finansowymi (akcje i obligacje) i niefinansowymi (np. dzieła sztuki i metale szlachetne), jak również ułatwić pozyskiwanie środków z crowdfundingu. GPW Private Market powstaje na bazie technologii blockchain (Wideokomentarz..., 2021). Pierwszy etap wdrożenia tej inicjatywy stanowiło uruchomienie platformy crowdfundingowej Raisemana, która ma umożliwić producentom gier pozyskiwanie środków na produkcję oraz dystrybucję swoich tytułów gier w zamian za tokeny (Uruchomiono pierwszy etap..., 2020). Końcowym efektem prac nad projektem ma być 
powstanie zdecentralizowanej, regionalnej giełdy europejskiej, współtworzonej z partnerskimi giełdami z krajów z tej części Europy (Wideokomentarz..., 2021).

Technologia blockchain wdrażana jest również jako rozwiązanie problemu cyfrowego trwałego nośnika, czyli procesu służącego do cyfrowej dystrybucji dokumentów bankowych. Prace wdrożeniowe wykorzystujące technologię blockchain w tym celu prowadzą Biuro Informacji Kredytowej (BIK) we współpracy z firmą Billon (Platforma Blockchain BIK oparta na prywatnym blockchainie), Krajowa Izba Rozliczeniowa (rozwiązanie zastosowane w bankach PKO oraz BNP Paribas), Alior Bank (w oparciu o blockchain publiczny Ethereum) oraz Atende (dla banków spółdzielczych) (Uryniuk, 2020). Warto zaznaczyć, że Billon przygotowuje, oparte na prywatnym blockchainie, rozwiązania oferujące zaufane zarządzanie dokumentami, produkty płatnicze i tokenizację aktywów. Billon Solutions sp. z o.o. jest na razie jedynym podmiotem, który w 2019 roku otrzymał od KNF licencję instytucji pieniądza elektronicznego ${ }^{35}$ (Billon, 2021). Billon jest tylko jednym $\mathrm{z}$ wielu młodych przedsiębiorstw i start-upów działających w Polsce, które wdrażają innowacyjne rozwiązania i usługi oparte na technologii blockchain $^{36}$.

\subsection{Podsumowanie}

Technologia łańcucha bloków (blockchain) i jej liczne zastosowania są obecnie jednym z najszerzej dyskutowanych tematów w obszarze cyfrowej gospodarki. Zastosowań tej technologii wymienić można wiele ${ }^{37}$. Pierwszym i przełomowym pomysłem było wykorzystanie technologii do stworzenia pierwszej kryptowaluty bitcoina. Szybko jednak okazało się, że blockchain znajdzie zastosowanie w głównym nurcie biznesu. Unikalne cechy blockchaina, dzięki którym eliminuje się potrzebę pośredników i zapewnia niezmieniany, zaufany i niezaprzeczalny zapis danych, umożliwiają wdrożenie całego wachlarza rozwiązań w takich obszarach, jak: usprawnienie systemów transakcyjnych, śledzenie aktywów i audytowanie danych oraz zarządzanie danymi. Blockchain może służyć płatnościom i rozliczeniom, dystrybucji treści cyfrowych, wykrywaniu fałszerstw i oszustw, planowaniu i kontroli dostaw czy zarządzaniu danymi publicznymi. $Z$ tego powodu dalsze wykorzystanie technologii blockchain wydaje się w zasadzie nieuniknione. Przy

${ }^{35}$ Billon Financial Ltd. jest ponadto zarejestrowana od 2017 roku jako mała instytucja pieniądza elektronicznego przez brytyjskiego regulatora Financial Conduct Authority. Spółki Billon Solutions sp. z o.o. i Billon Financial Ltd. współtworzą grupę kapitałową Billon.

${ }^{36}$ Listę start-upów blockchainowych w Polsce można znaleźć w raporcie Blockchain Compass 2018 (Fundacja Startup Poland, 2018).

${ }^{37}$ Zob. na przykład (Dhillon, Metcalf i Hooper, 2018). 
odpowiednim stosowaniu, a także wykorzystaniu szans i niwelowaniu zagrożeń, technologia blockchain stanie się wkrótce ułatwiającą funkcjonowanie na rynku finansowym codziennością.

\section{Bibliografia}

Acheson, N. (2017). China's ICO Ban: Understandable, reasonable and (probably) temporary. Coindesk. Pobrane 12 września 2017 z https://www.coindesk.com/chinas-icoban-understandable-reasonable-probably-temporary

Baur, D. G., Hong, K. i Lee, A. D. (2017). Bitcoin: Medium of exchange or speculative assets?. Journal of International Financial Markets, Institutions \& Money, 54, 177-189.

Bech, M. i Garratt, R. (2017, Septempber). Central bank cryptocurrencies. BIS Quarterly Review, 55-70.

Billon. (2021). Rozwiazania biznesowe. Pobrane 7 czerwca $2021 \mathrm{z}$ https://billongroup. $\mathrm{com} / \mathrm{pl} /$

Blockchain w Polsce. Możliwości i zastosowania. (2018). Pobrane 7 czerwca 2021 z https:// branden.biz/wp-content/uploads/2018/12/blockchain_w_polsce._mo\%C5\%BCliwo$\%$ C5\%9Bci_i_zastosowania.pdf

Bullmann, D., Klemm, J. i Pinna, A. (2019). In search of stability in crypto-assets: are stablecoins the solution? (European Central Bank Occasional Paper Series No. 230). Pobrane z https://www.ecb.europa.eu/pub/pdf/scpops/ecb.op230 d57946be3b.en.pdf

Calle, G. i Zalles, D. B. (2019). Will businesses ever use stablecoins?. (R3 Reports). Pobrane z www.r3.com/reports/will-businesses-ever-use-stablecoins/.

Coinmarketcap. (2021). Today's cryptocurrency prices by market cap. Pobrane 1 czerwca $2021 \mathrm{z}$ https://coinmarketcap.com

Cryptocurrency statistics. (2021). Pobrane 1 czerwca $2021 \mathrm{z}$ https://bitinfocharts.com/

Deloitte. (2019). Are token assets the securities of tomorrow?. Pobrane 7 czerwca 2021 z https:/www2.deloitte.com/content/dam/Deloitte/lu/Documents/technology/lu-token-assets-securities-tomorrow.pdf

Deloitte. (2020). C-suite briefing. 5 blockchain trends for 2020. Pobrane 7 czerwca 2021 z https://www2.deloitte.com/content/dam/Deloitte/ie/Documents/Consulting/Blockchain-Trends-2020-report.pdf

Dhillon, V., Metcalf, D. i Hooper, M. (2018). Zastosowania technologii blockchain, Warszawa: PWN.

Dwyer, G. P. (2015). The economics of Bitcoin and similar private digital currencies. Journal of Financial Stability, 17, 81-91.

ESMA. (2017). ESMA alerts investors to the high risks of Initial Coin Offerings(ICOs). Pobrane z https://www.esma.europa.eu/sites/default/files/library/esma50-157-829_ico_ statement_investors.pdf

Europejski Bank Centralny. (2012). Virtual currency schemes. Pobrane z https://www.ecb. europa.eu/pub/pdf/other/virtualcurrencyschemes201210en.pdf 
Europejski Bank Centralny. (2019). Crypto-assets: Implications for financial stability, monetary policy, and payments and market infrastructures (Occasional Paper Series No. 223/May 2019). Pobrane z https://www.ecb.europa.eu/pub/pdf/scpops/ecb.op223 3ce14e986c.en.pdf

Forecast: Blockchain business Value, Worldwide, 2017-2030. (2017). Pobrane z https:// www.gartner.com/en/documents/3627117/forecast-blockchain-business-value-worldwide-2017-2030

Fundacja Startup Poland. (2018). Blockchain Compass 2018. Pobrane 7 czerwca 2021 $\mathrm{z}$ https://drive.google.com/file/d/1su4GkrgCoZ60gXRyXin7eC1wpq5fXG9U/view

Glaser, F., Zimmermann, K., Haferkorn, M., Weber, M. C. i Siering, M. (2014). Bitcoinasset or currency? Revealing users' hidden intentions. Pobrane z https://papers.ssrn. com/sol3/papers.cfm?abstract_id=2425247

Hern, A. (2021). New cryptocurrency Chia blamed for hard drive shortages. The Guardian. Pobrane 26 maja 2021 z https://www.theguardian.com/technology/2021/may/26/newcryptocurrency-chia-blamed-for-hard-drive-shortages

Hileman, G. i Rauchs, M. (2017). Global cryptocurrency benchmarking study. Cambridge: Cambridge Centre for Alternative Finance. Pobrane z https:/www.jbs.cam.ac.uk/wp-content/uploads/2020/08/2017-04-20-global-cryptocurrency-benchmarking-study.pdf

ID2S. (2021). About us. Pobrane 7 czerwca 2021 z www.id2s.eu

Irrera, A. (2018). Banks unlikely to process payments with distributed ledgers for now, says Ripple. Reuters. Pobrane 13 czerwca 2018 z https:/www.reuters.com/article/us-blockchain-ripple-idUSKBN1J92JG

KDPW. (2021). Platforma blockchain dla rynku kapitałowego. Pobrane 7 czerwca 2021 z https://blockchain.kdpw.pl/

Kołodziejczyk, H. i Jarno, K. (2020). Stablecoin - the stable cryptocurrency. Studia BAS, 3(63), 155-170.

Marchewka-Bartkowiak, K. (2019). Tokeny i tokenizacja - nowe zjawisko technologiczne w finansach. W: W. Przybylska-Kapuścińska i K. Perez (red.), Polityka pieniężna i rynki finansowe wobec wyzwań gospodarki 4.0 (s. 193-205). Warszawa: CeDeWu.

Marszałek, P. (2019). Kryptowaluty - pojęcie, cechy, kontrowersje. Studia BAS, 57(1), $105-125$.

Memoria, F. (2017). Hacker Nets over \$500,000 after Hacking Enigma before ICO Date. CCN. Pobrane 21 sierpnia $2017 \mathrm{z}$ https://www.ccn.com/hacker-nets-over-500000-afterhacking-enigma-before-its-ico-date/

OECD. (2019). Initial coin offerings (ICOs) for SME financing. Pobrane z www.oecd.org/ finance/initial-coin-offerings-for-sme-financing.htm

Otani, A. (2021). Elon musk has become bitcoin's biggest influencer, like it or not. The Wall Street Journal. Pobrane 23 maja 2021 z https://www.wsj.com/articles/elon-muskhas-become-bitcoins-biggest-influencer-like-it-or-not-11621762202

Piech, K. (red.). (2017). Podstawy korzystania z walut cyfrowych. Pobrane z https://www. gov.pl/documents/31305/436699/Podstawy+walut+cyfrowych.pdf/7a000d7b-2544f2c7-b532-991a3ee6049a

Popper, N. (2020). Cryptocurrency Company Ripple is sued by S.E.C. The Ney York Times, Pobrane 22 grudnia $2020 \mathrm{z}$ https:/www.nytimes.com/2020/12/21/technology/ripple-cryptocurrency-sec-lawsuit.html 
PwC's global blockchain survey. (b.d.). Pobrane 7 czerwca 2021 z https://www.pwc.com/ gx/en/industries/technology/blockchain/blockchain-in-business.html

Shane, D. (2019). A crypto exchange may have lost $\$ 145$ million after its CEO suddenly died. CNN Business. Pobrane 6 lutego 2019 z https://edition.cnn.com/2019/02/05/tech/ quadriga-gerald-cotten-cryptocurrency/index.html

Tapscott, D. i Tapscott, A. (2016, 10 maja). The impact of the blockchain goes beyond financial services. Harvard Business Review. Pobrane 7 czerwca $2021 \mathrm{z}$ https://hbr. org/2016/05/the-impact-of-the-blockchain-goes-beyond-financial-services

The blockchain report 2020. (2020). Pobrane z https://www.cbinsights.com/research/report/blockchain-report-2020/

Uruchomiono pierwszy etap inicjatywy „GPW Private Market”. (2020, 29 września). GPW. Pobrane z https://www.gpw.pl/aktualnosc?ph_main_01_start=show\&cmn_id=109996$\&$ title $=$ Uruchomiono + pierwszy + etap + inicjatywy $+\%$ E2\%80\%9EGPW + Private + Mark et $\% \mathrm{E} 2 \% 80 \% 9 \mathrm{D}$

Uryniuk, J. (2020, 16 kwietnia). BIK chwali się pierwszym wdrożeniem systemu trwałego nośnika opartego o blockchain. Chce rozwijać projekt. Cashless. Pobrane 7 czerwca $2021 \mathrm{z}$ https://www.cashless.pl/7544-bik-billon-trwaly-nosnik-blockchain

Wideokomentarz GPW: GPW Private Market. (2021, 2 listopada). GPW. Pobrane z https:// www.gpw.pl/aktualnosc?ph_main_01_start=show\&cmn_id=111686\&title=Wideokom entarz+GPW\%3A+GPW+Private+Market

Wikarczyk, A. (2019). Rynek kryptowalut - sytuacja bieżąca i kierunki rozwoju. Studia $B A S, 57(1), 143-160$. 